\title{
PERANCANGAN SISTEM INFORMASI PENGARSIPAN DATA- DATA PRODUKSI PADA PT. KURALON INDAH SEJAHTERA
}

\author{
Nur Azizah ${ }^{1}$ \\ Euis Sitinur Aisyah ${ }^{2}$ \\ Recky Taemima ${ }^{3}$ \\ Dosen STMIK Raharja ${ }^{1,2}$ \\ STMIK Raharja Jurusan Sistem Informasi ${ }^{3}$ \\ Jl. Jendral Sudirman no.40, Modern, Cikokol Tangerang ${ }^{1,2,3}$ \\ Email :nur.azizah@raharja.info ${ }^{1}$,euis@raharja.info ${ }^{2}$,recky@raharja.info ${ }^{3}$
}

\begin{abstract}
ABSTRAK
Saat ini PT Kuralon Indah Sejati masih menggunakan proses manual untuk pengarsipan datadata produksi yaitu dengan menyimpan di filling cabinet dan menyimpannya kedalam buku sehingga banyak mengeluarkan tumpukan kertas dan butuh waktu lama dalam pencarian. Dikarenakan banyak kendala yang dihadapi oleh admin dalam penyimpanan arsip produksi. Oleh karena itu dibuat lah sistem pengarsipan berbasis web dan sudah terkomputerisasi agar kendala-kendala yang dihadapi dapat terselesaikan. Sistem dibuat dengan Teknik analisa data yang digunakan adalah analisa SWOT (Strength, Weakness, Opportunities, Threats) Analisis SWOT mencakup lingkungan ekstern dan lingkungan intern. Metode Perancangan yang digunakan adalah SDLC(system design life cycle) dan dibantu oleh UML(unified modeling language) dalam pembuatan diagramnya. Metode testing yang digunakan yaitu black box serta tahap terakhir yaitu implementasi. Kesimpulan setelah adanya sistem ini diharapkan dapat mempermudah admin dalam proses pengarsipan.
\end{abstract}

Kata kunci : UML, Pengarsipan, Produksi.

\begin{abstract}
Currently PT Kuralon Indah Sejati still uses manual process for archiving production data that is by storing in filling cabinet and store it into book so many out of pile of paper and take long time in search. Due to the many obstacles faced by the admin in the storage of production archives. Therefore created a web-based filing system and has been computerized so that the constraints faced can be resolved. System is made by Data analysis technique used is SWOT analysis (Strength, Weakness, Opportunities, Threats) SWOT analysis covers external environment and internal environment. Design method used is SDLC (system design life cycle) and assisted by UML (unified modeling language) in making the diagram. The testing method used is the black box and the last stage is the implementation. The conclusion after the existence of this system is expected to facilitate admin in the process of filing.
\end{abstract}

Keywords: UML, Archiving, Production.

\section{PENDAHULUAN}

Teknologi informasi dan komunikasi saat ini sudah semakin maju dan berkembang, terutama di bidang sistem informasi yang saatini sudah menjadi kebutuhan yang sangat mendasar bagi setiap instansi pemerintah maupun perusahaan. 
Saat ini peranan sistem informasi telah menjadi peranan penting yang berpengaruh bagi kemajuan instansi maupun perusahaan. Sebagai alat bantu dalam pengolahan data, kebutuhan akan suatu sistem informasi setiap perusahaan atau instansi sangat membutuhkan informasi yang akurat.

Namun dalam kenyataan hal tersebut terkadang tidak sesuai dengan keinginan dan harapan, dikarenakan masih terbatasnya sistem informasi yang digunakan.

Agar suatu perusahaan dapat bersaing maka diperlukan sistem informasi yang baik dan dapat mempermudah dalam pekerjaan terutama dalam proses pengolahan data.

Berdasarkan pengamatan dan wawancara dengan pihak terkait, Saat ini PT Kuralon Indah Sejahtera masih menggunakan proses manual untuk pengarsipan data-data produksi yaitu dengan menyimpan di filling cabinet dan menyimpannya kedalam buku sehingga banyak mengeluarkan tumpukan kertas dan butuh waktu lama dalam pencarian.

Dalam upaya untuk mengatasi permasalahan- permasalahan yang ada perlu dikembangkan sistem yang lebih baik untuk pengarsipan data khususnya data produksi yang nanti nya dapat digunakan sebagai pendukung keputusan.

\section{METODE PENELITIAN}

\section{Metode Analisa}

Analisis SWOT adalah sebuah metode perencanaan strategis yang di gunakan untuk mengevaluasi Strengths, Weakness, Opportunities, dan Threats. dalam suatu proyek atau bisnis usaha. Hal ini melibatkan penentuan tujuan usaha bisnis atau proyek dan mengidentifikasi faktor-faktor internal dan eksternal yang baik dan menguntungkan untuk mencapai tujuan itu. (Grewal \& Levy, 2008) dalam Robi Setyawan (2015:34) ${ }^{[4]}$ Teori Analisis SWOT adalah sebuah teori yang di gunakan untuk merencanakan sesesuatu hal yang di lakukan dengan SWOT. SWOT adalah sebuah singkatan dari S adalah Strenghts atau kekuatan, W adalah Weakness atau kelemahan, $\mathrm{O}$ adalah Opportunities atau kesempatan, dan $\mathrm{T}$ adalah Threats atau ancaman. SWOT ini biasa digunakan untuk menganalisis suatu kondisi dimana akan di buat sebuah rencana untuk melakukan suatu program kerja (Buchari Alma, 2008) dalam Robi Setyawan (2015: 35) ${ }^{[4]}$

\section{Metode Pengumpulan Data}

Dalam tahap pengumpulan data untuk penelitian ini, penulis berusaha mengumpulkannya secara bertahap dan data-data yang dikumpulkan adalah data yang relevan dengan judul yang diambil.

Metode Pengamatan (Observasi Research), yaitu dengan mengumpulkan data secara langsung dengan observasi lapangan atau pengamatan terhadap proses pemeliharaan maintenance aset IT.

Metode Wawancara (Interview Research), metode ini dilakukan dengan cara melakukan tanya jawab dengan beberapa narasumber secara langsung ditempat penelitian berlangsung. Metode ini dilakukan agar data yang di dapatkan lebih detail serta memperkuat data sebelumnya saat melakukan observasi lapangan.

Metode Studi Pustaka (Literature Research), untuk mendapatkan informasi yang terkait dengan permasalahan yang akan diteliti, penulis mengumpulkan data dari berbagai buku, jurnal, serta berbagai laporan guna mendapatkan gambaran secara teoritis dalam pembuatan laporan penelitian ini sebagai acuan. 


\section{LITERATURE REVIEW}

Berikut ini adalah penelitian yang telah dilakukan dan memiliki korelasi searah dengan penelitian yang akan dibahas dalam Skripsi ini, antara lain :

1. Penelitian yang dilakukan oleh Basri dan Joni Devitra pada Jurnal Manajemen Sistem Informasi Vol. 2 No. 1 (2017) ${ }^{[2]}$

Penelitian ini berjudul "Analisis dan Perancangan Sistem Informasi Pengelolaan Arsip Berbasis Web (Studi Kasus : Pada Komisi Pemilihan Umum (KPU) Kabupaten Tebo)". Tujuan utama penelitian ini adalah pembuatan sistem informasi pengelolaan arsip berbasis web yang dapat mempermudah kerja petugas dalam melakukan pengelolaan dan pencarian arsip.

2. Penelitian yang dilakukan olehYeni Kurniawati dan Ika Ratna Indra Astutik pada Jurnal Sistem Informasi Teknologi Informatika dan Komputer Vol. 8 No. 1 (2017) $^{[3]}$

Penelitian ini berjudul "Sistem Informasi Efilling Dokumen Desa Berbasis Web (Studi Kasus :Desa Bangun-Pungging)”. Penelitian ini bertujuan untuk merancang sistem informasi yang dapat mempermudah admin, staff dan masyarakat dalam proses pengarsipan data dan pencarian data dengan lebih efektif dan efisien.

3. Penelitian yang dilakukan oleh Riwan Tri Haryono, Bambang Eka Purnama, dan Sukadi pada Jurna IJNS (2013) ${ }^{[6]}$

Penelitian ini berjudul "Perancangan Sistem Informasi Pengolahan Data Produksi Dan Penjualan Pada Pabrik Penggergajian Batu CV. Bumi Indah Persada". Tujuan dari penelitian ini adalah Mempermudah dan mempercepat analisa sehingga perusahaan dapat dengan cepat menentukan langkah dan kebijakan dengan berdasarkan hasil pelaporan.

4. Penelitian yang dilakukan oleh Dahlan Abdullah, Cut Yusra Novita dan Cut Ita Erliana pada Jurnal SISFOTENIKA Vol. 4 No. 2 (2014) ${ }^{[1]}$

Penelitian ini berjudul "Perancangan Sistem Informasi Pengarsipan Pada PDAM Tirta Mon Pase Aceh Utara". Penelitian inibertujuan untuk membangun suatu sistem informasi yang dapat membantu pegawai PDAM Tirta Mon Pase dalam melakukan pengolahan dan pengarsipan data surat sehingga proses pencarian surat yang dibutuhkan dapat ditemukan dengan lebih cepat.

5. Penelitian yang dilakukan oleh Achmad Sidik, Lilis Sakuroh dan Diana Pratiwi pada Jurnal SISFOTEK GLOBAL Vol. 7 No. $2(2017)^{[5]}$

Penelitian ini berjudul "Perancangan Sistem Informasi Fillingdi PT BCA Cabang MH Thamrin Tangerang".Penelitian ini bertujuan untuk merancang suatu sistem informasi pengarsipan atau filling berkasyang mempermudah proses pencarian, penyimpanan dan monitoring berkas.

Maka, dari kelima penelitian tersebut dapat disimpulkan bahwa penelitian ini berhubungan erat dengan referensi penelitian yang diambil dari penelitian sebelumnya namun berbeda dalam hal objek penelitian dan metodenya. Penelitian ini menggunakan metode analisis SWOT dalam proses penyelesaian masalah yang dihadapi dan menggunakan teknik pengujian sistem menggunakanBlack Box Testing. 


\section{PEMBAHASAN}

Berikut ini merupakan analisis SWOT yang diusulkan dimana pada analisis ini mengidentifikasi Strength (kekuatan) dan Weakness (kelemahan) yang merupakan faktor internal dan Opportunities (peluang) dan Threats (ancaman) yaitu merupakan faktor eksternal.Berikut ini merupakan table analisa SWOT yang diusulkan :

\section{Strength (S) (Kekuatan)}

Strength dalam hal ini merupakan kekuatan program pengarsipan data produksi. Proses penginputan lebih cepat dan aman dalam penyimpanan data produksi karena sering terjadi kehilangan data.

\section{Weakness(kelemahan)}

Weakness dalam hal ini merupakan kelemahan program pengarsipan data peroduksi. Harus ada internet dan gadget yang mendukung untuk mengakses data dan mengelola data produksi

\section{Opportunities (peluang)}

Opportunities dalam hal ini merupakan peluang program pengarsipan data produksi. Penyelesaian kerjaan lebih cepat karena pengiriman data sudah menggunakan sistem online dan dapat dilihat seluruh user yang terdaftar di sistem dalam waktu bersamaan

\section{Threats(Ancaman)}

Threats dalam hal ini merupakan peluang program pengarsipan data produksi. Sistem yang digunakan dapat terkena virus karena sistem sudah terhubung ke internet.

Berdasarkan identifikasi analisis SWOT yang dilakukan, maka selanjutnya melakukan analisa untuk mencari strategi menggunakan table matriks SWOT. Matriks SWOT yaitu matriks yang menggambarkan secara jelas peluang yang tersedia dengan menggunakan strategi S-O dan kekuatan untuk mengatasi sebuah ancaman dengan menggunakan strategi S-T, lalu analisis strategi yang bertujuan untuk mengurangi kelemahan yang dimiliki sistem dan untuk meraih sebuah peluang yang ada dengan menggunakan strategi W-O, mengatasi ancaman dengan menggunakan strategi W-T. berikut ini merupakan table Matriks SWOT :

\section{$\boldsymbol{S}-\boldsymbol{O}$ (strength-opportunities)}

$\boldsymbol{S}$-O disini digunakan untuk menggambarkan secara jelas peluang yang tersedia dengan menggunakan strategi. Menerapkan sistem modul berbasis web dengan tujuan memudahkan admin mencari dan mengirim data dengan lebih cepat serta penginputan lebih mudah dan aman.

\section{$S-\boldsymbol{T}$ (strength-threats)}

$\boldsymbol{S}-\boldsymbol{T}$ disini digunakan untuk mengatasi sebuah ancaman dengan mengggunakan strategi. Memudahkan karyawan untuk mencuri data perusahaan karena data dapat diakses dengan mudah dimana saja dan kapan saja. 
$\boldsymbol{W}-\boldsymbol{O}$ (weakness-opportunities)

$\boldsymbol{W}-\boldsymbol{O}$ disini digunakan analisis strategi yang bertujuan untuk mengurangi kelemahan yang dimiliki sistem dan untuk meraih sebuah peluang yang ada dengan menggunakan strategi. Penyelesaian pekerjaan lebih cepat tapi membutuhkan training dan dapat menambah biaya operasional.

\section{$\boldsymbol{W}-\boldsymbol{T}$ (weakness-threats)}

$\boldsymbol{W}-\boldsymbol{T}$ disini digunakan mengatasi ancaman dengan menggunakan strategi. Dapat terkena virus internet karena mengakses internet dengan menggunakan gadget.

Setelah melakukan analisa serta penelitian yang dilakukan dalam proses pengarsipan yang berjalan saat ini ternyata belum adanya media penyimpanan arsip perusahaan yang bisa diakses secara online dimana saja dan kapan saja. Maka tahap selanjutnya yang peneliti lakukan adalah membahas mengenai sistem usulan untuk melakukan pengembangan sistem pengarsipan berbasis web yang bertujuan untuk mempermudahkan admin dalam melakukan penyimpanan dan mempermudah user dalam

mengakses arsip yang dibutuhkan agar lebih efektif dan efisien. Adapun sistem yang diusulkan untuk prosedur yang baru ini yaitu dengan menggunakan UML untuk menggambarkan Use Case Diagram, Activity Diagram, dan Sequence Diagram.

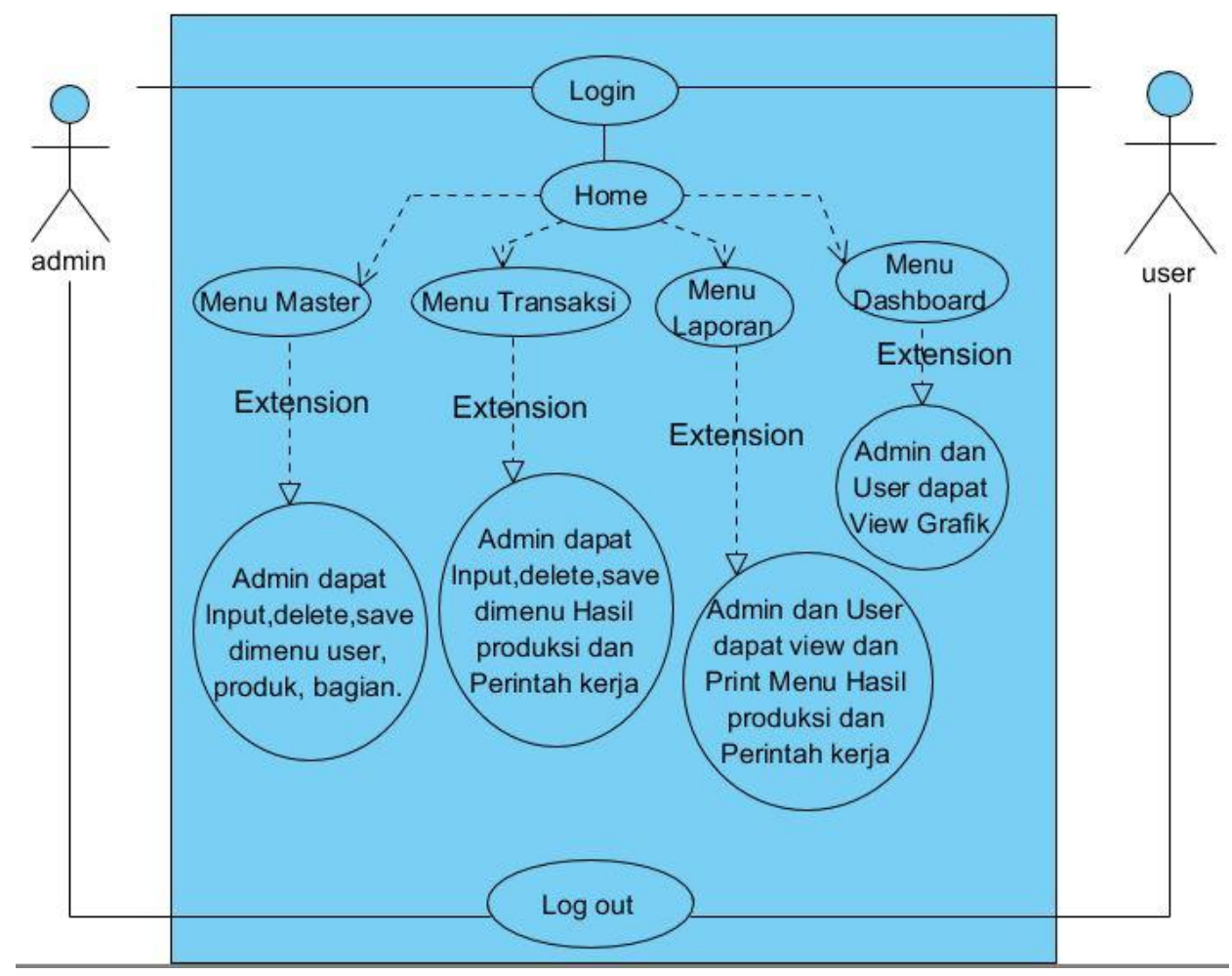

Gambar 1. Usecase Diagram

Pada tampilan di atas (gambar 1), Terdapat 2 actor yang melakukan kegiatan didalam sistem yaitu, Admin, User. Terdapat 7 Use Case yang dapat dilakukan oleh actor tersebut yaitu, Login, Home, Menu Dashboard, Menu master, Menu transaksi, Menu laporan, Logout. 
Kemudian terdapat Terdapat 4 Extension yaitu, Input, delete, save di menu user, produk, bagian, Input, delete, save di menu hasil produksi dan perintah kerja.(Transaksi), View dan print di menu hasil produksi dan perintah kerja (Laporan) View grafik pada menu dashboard.

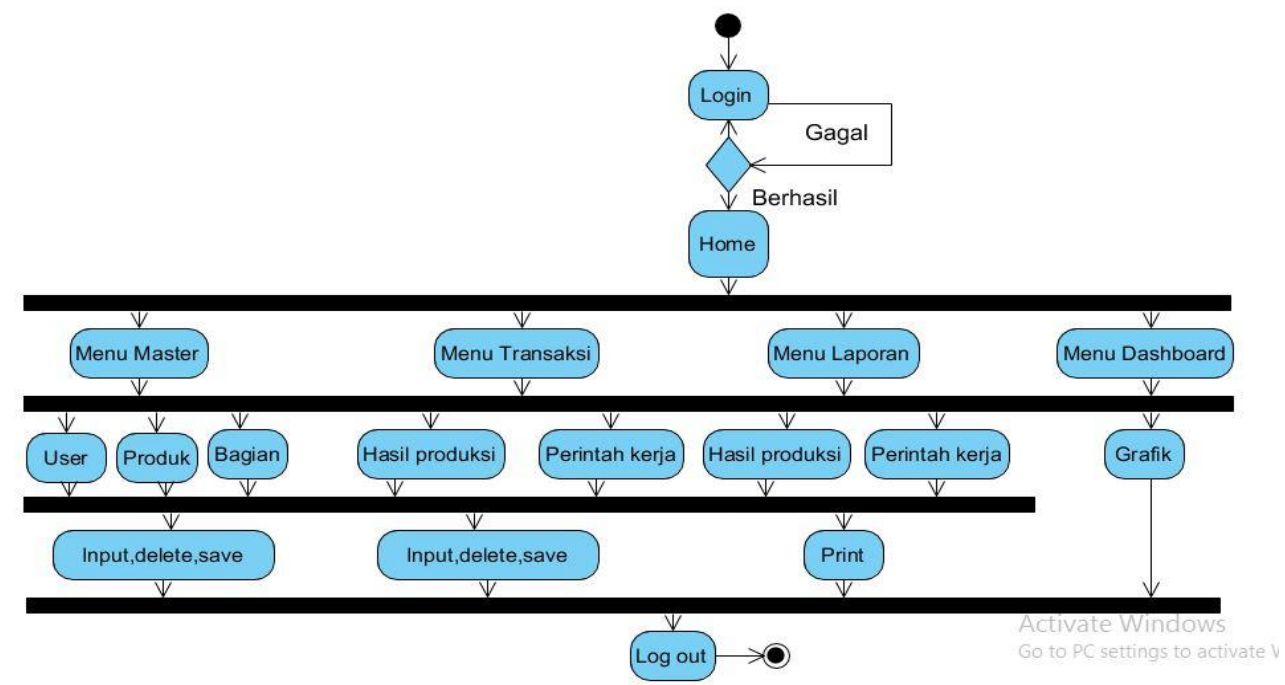

Gambar 2. Activity Diagram

Pada tampilan di atas (gambar 2), Terdapat 1 Initial Node, sebagai awal objek. Terdapat 18 action state dari sistem yang mencerminkan eksekusi dari suatu aksi. Login, Home, Menu master, Menu Dashboard, Menu transaksi, Menu laporan, User, Produk, Bagian, Hasil produksi, Perintah kerja, Grafik, Input,delete,save, Print, Logout. 1 Final Node, sebagai objek yang diakhiri.

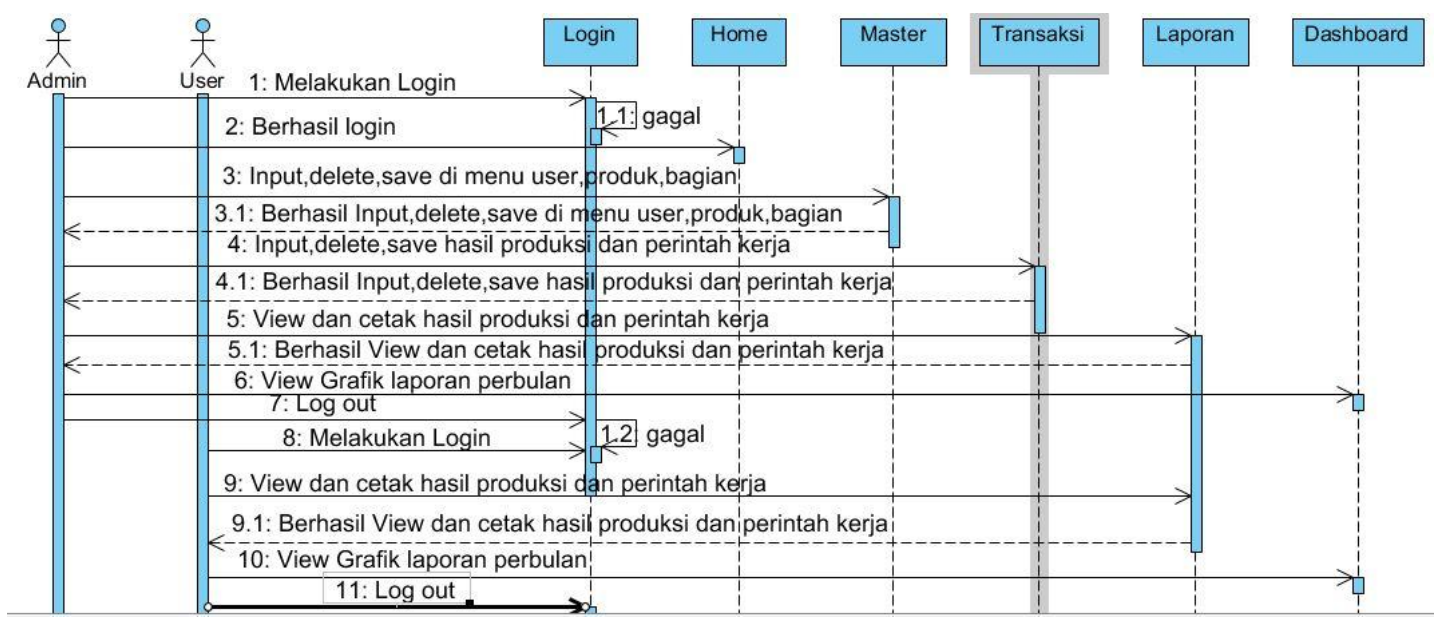

Gambar 3. Sequence diagram

Berdasarkan gambar 3.Sequence Diagram diatas terdiri atas, Terdapat 2 actor yang melakukan kegiatan yaitu Admin dan User, Terdapat 6 lifeline yaitu Login, Home, Master, Transaksi, Laporan, Dashboard, Logout. Terdapat 2 selfmessage yaitu 1.1 gagal login, 1.2 gagal login. Terdapat 13 message yang menggambarkan komunikasi, yaitu : Admin melakukan login, Admin berhasil login, Input, delete, save di menu user,produk,bagian, Berhasil input, delete, 
save di menu user,produk, bagian, Input, delete, save di menu hasil produksi dan laporan kerja, Berhasil input, delete, save di menu hasil produksi dan laporan kerja, View dan print hasil produksi dan laporan kerja, Berhasil View dan print hasil produksi dan laporan kerja , View grafik laporan perbulan, Admin logout, User login, User berhasil login, View dan print hasil produksi dan laporan kerja, Berhasil View dan print hasil produksi dan laporan kerja, View grafik laporan perbulan, User logout.

\section{IMPLEMENTASI}

\section{Sistem Informasi Data Produksi}

\section{Login System}

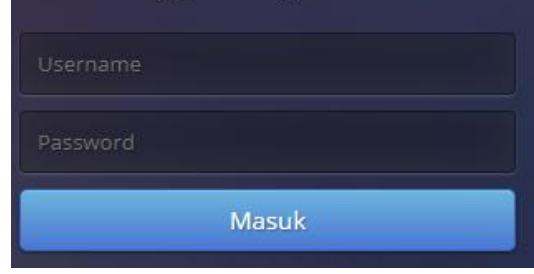

Gambar 4. Tampilan Login

Pada gambar di atas (gambar 4), merupakan tampilan login yang digunakan oleh admin jika ingin memasuki sistem dengan mengisi kolom username dan password.
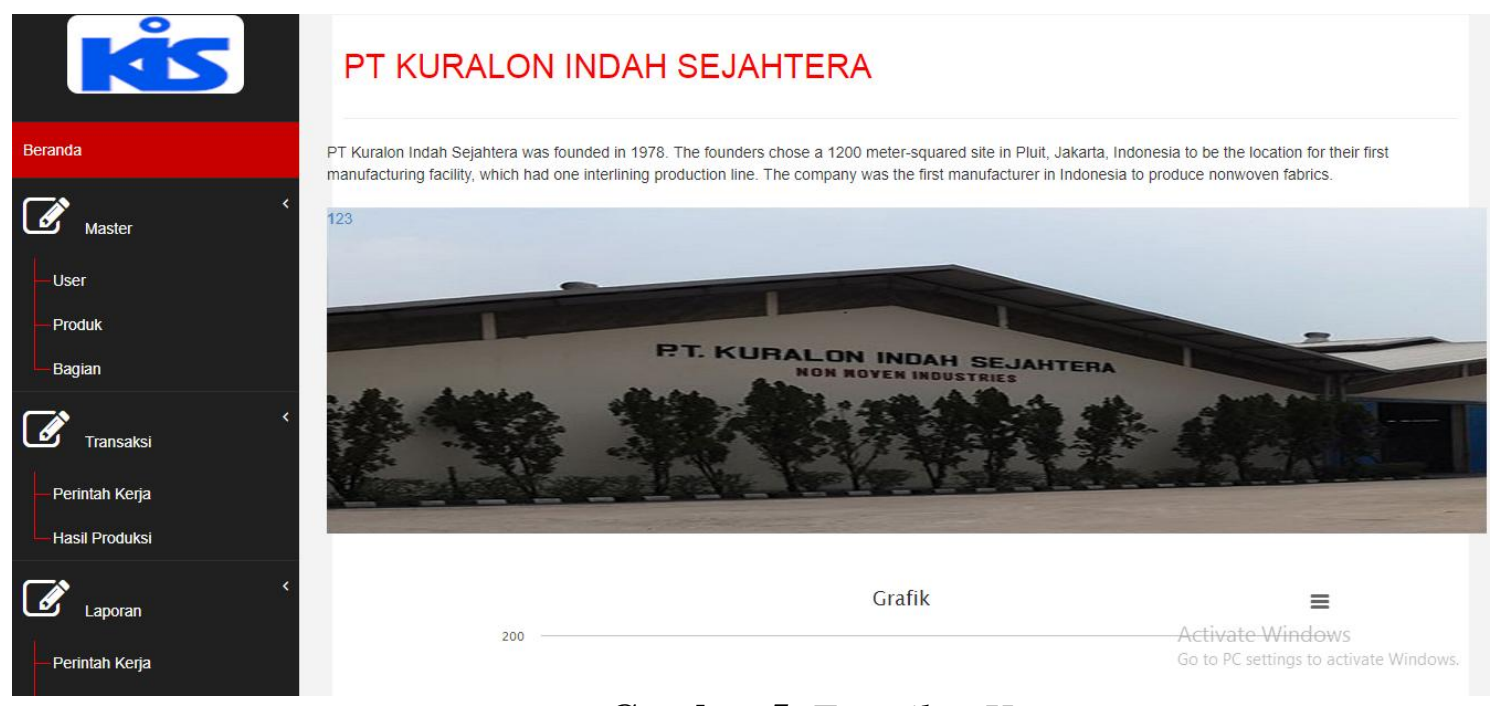

Gambar 5. Tampilan Home

Pada gambar di atas (gambar 5), merupakan tampilan awal atau home pada sistem yang digunakan oleh admindan user ketika memasuki sistem. 

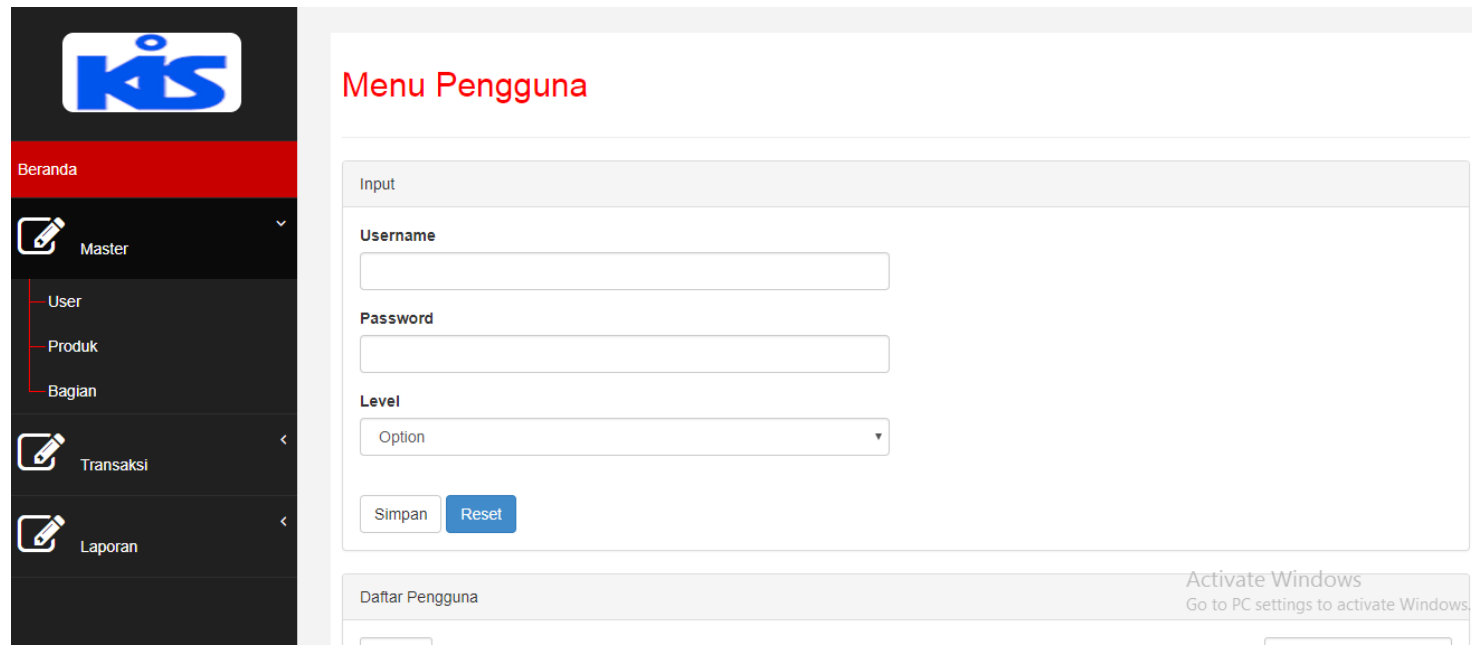

Gambar 6. Tampilan Menu Master user

Pada gambar di atas (gambar 6), merupakan tampilan menu master user yang di gunakan admin untuk menambah atau menghapus user pada sistem.
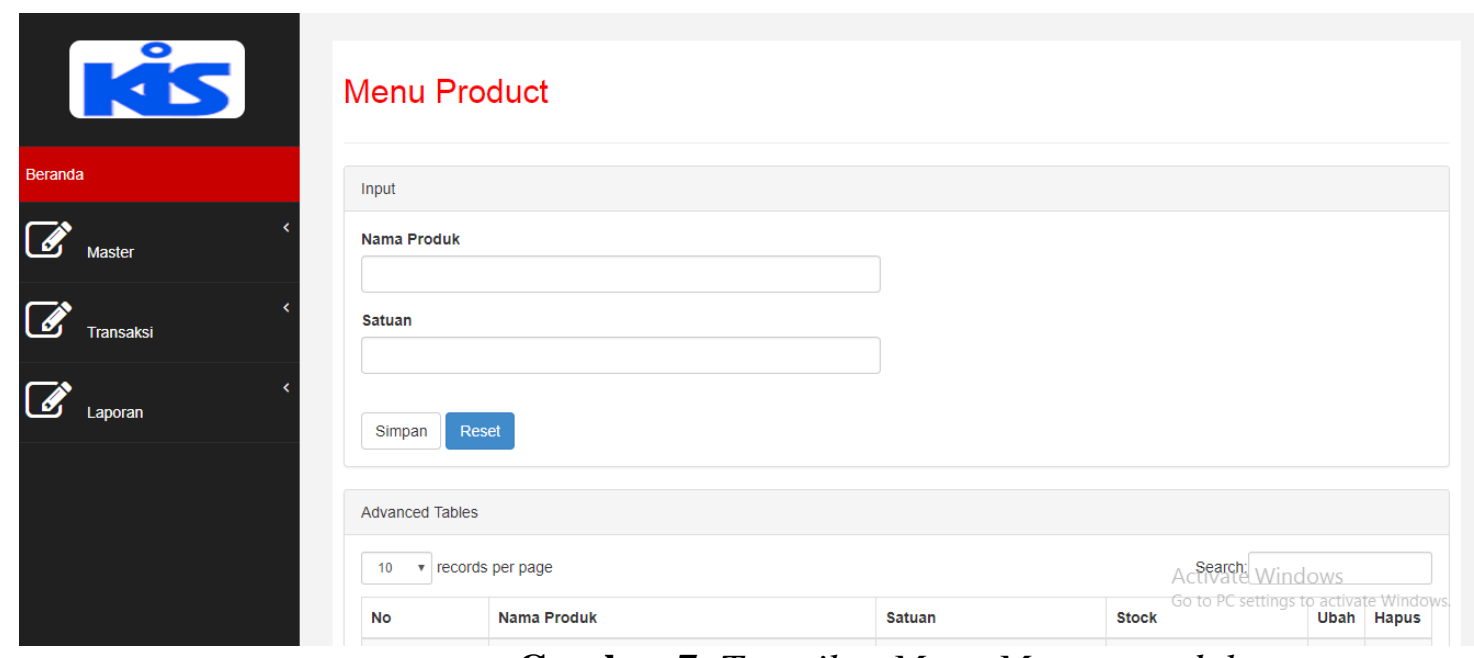

Gambar 7. Tampilan Menu Master produk

Pada gambar di atas (gambar 7), merupakan tampilan menu master user yang di gunakan admin untuk menambah atau menghapus produk pada sistem.

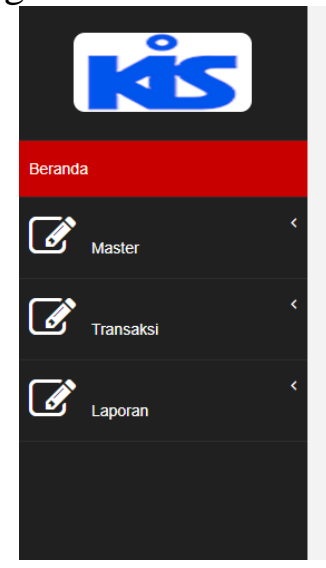

Menu Bagian

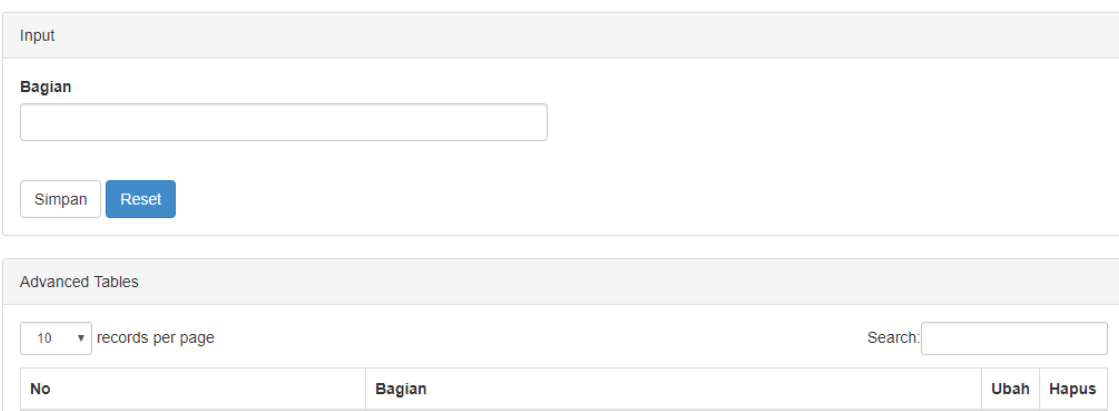

Gambar 8. Tampilan Menu master bagian 
Pada gambar di atas (gambar 8), merupakan tampilan menu master user yang di gunakan admin untuk menambah atau menghapus divisi pada sistem.
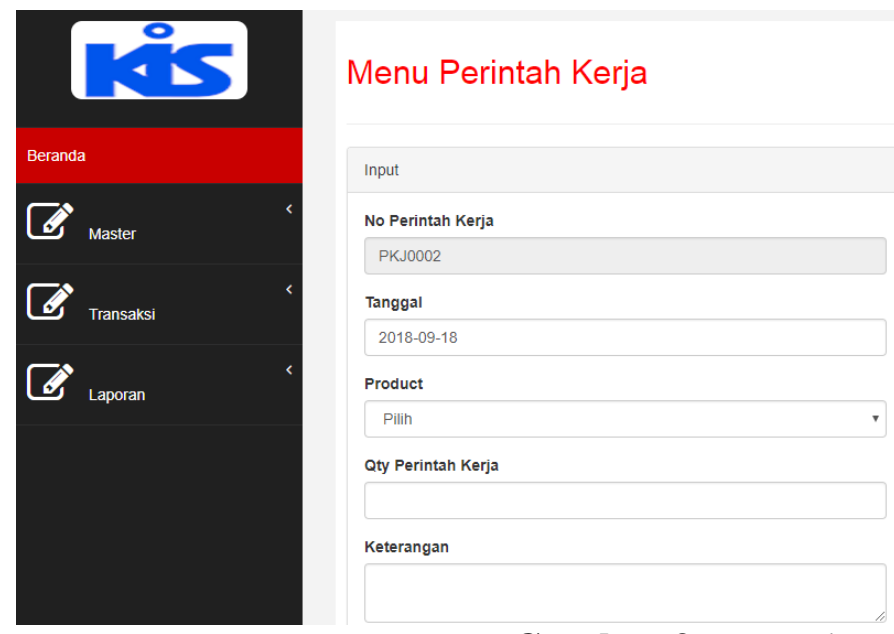

Gambar 9. Tampilan Menu Perintah Kerja

Pada gambar di atas (gambar 9), menampilkan menu untuk menginput perintah kerja yang sudah dikerjakan.
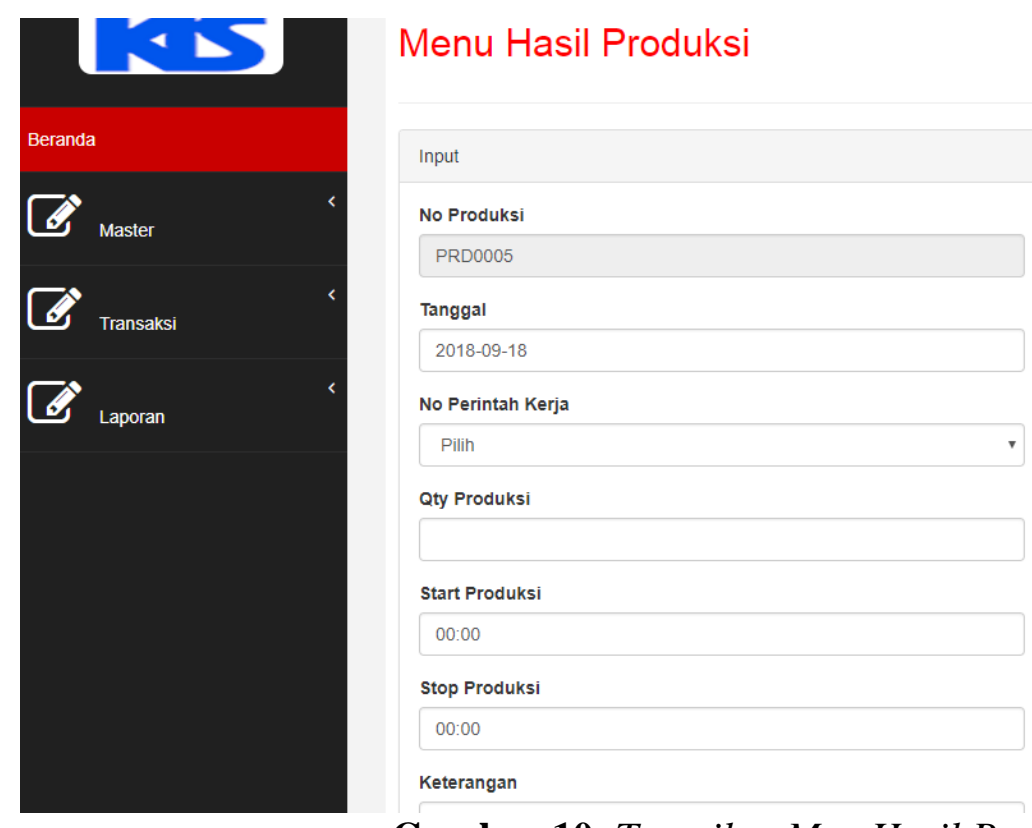

Gambar 10. Tampilan Meu Hasil Produksi

Pada gambar diatas(gambar 10), menampilkan menu untuk menginput hasil produksi yang didapat di setiap shift. 


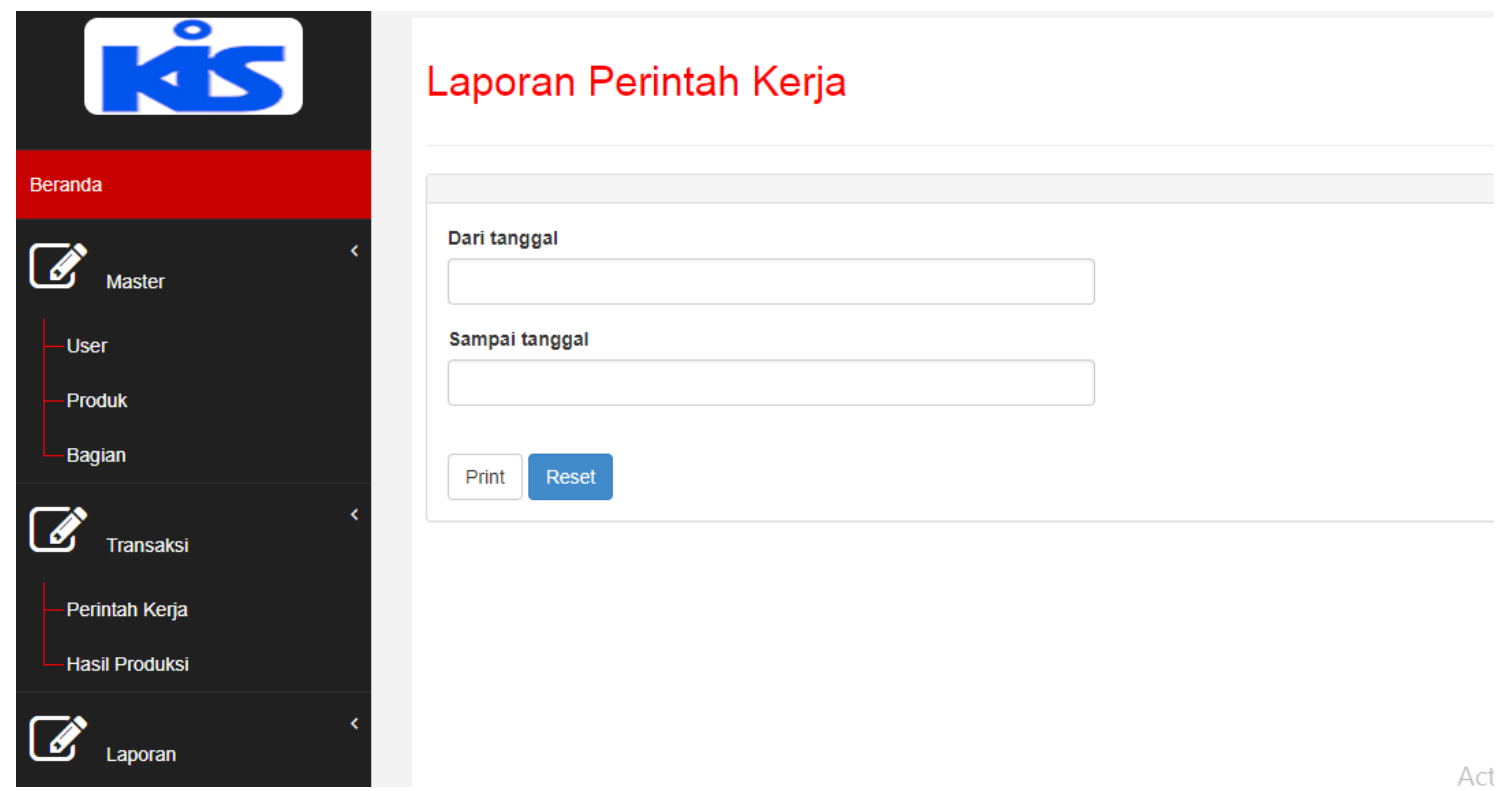

Gambar 11. Tampilan Menu Laporan Perintah Kerja

Pada gambar diatas (gambar 11), menampilkan menu pencarian untuk laporan perintah kerja pada perusahaan.

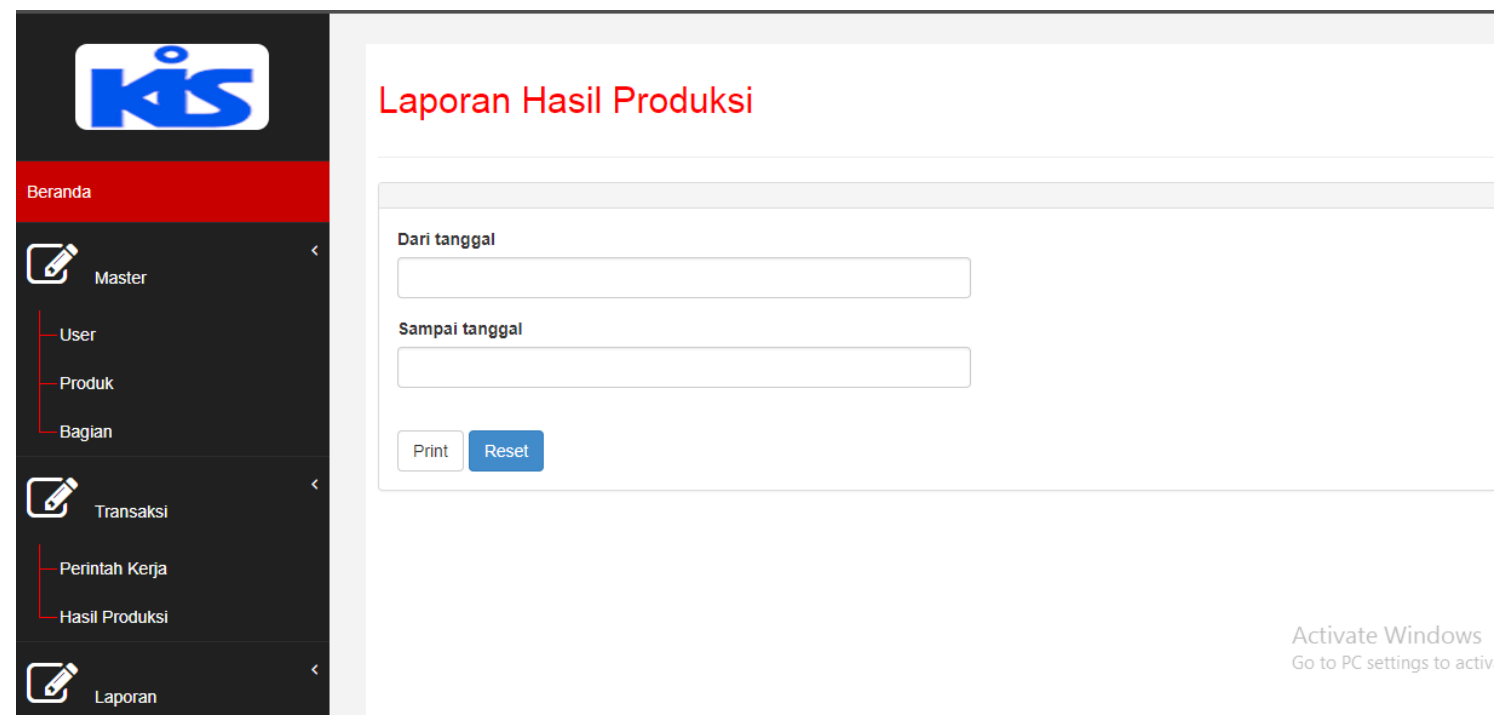

Gambar 12. Tampilan Menu Laporan Hasil Produksi

Pada gambar diatas (gambar 12), menampilkan menu pencarian hasil produksi perbulan pada perusahaan.

\section{KESIMPULAN}

Berdasarkan hasil penelitian dari sistem manajemen aset IT untuk pencatatan history maintenance, maka penulis dapat menarik kesimpulan sebagai berikut :

Sistem informasi pengarsipan data-data produksi pada PT. Kuralon Indah Sejahtera yang berjalan saat ini adalah sistem manual yang dimana sistem ini masih menggunakan tulis menulis diketas dan pengiriman data dari tangan ke tangan. Sistem data-data produksi 
yang berjalan pada PT. Kuralon Indah Sejahtera Tangerang sudah tertata rapi dalam pengarsipan tapi menghabiskan banyak ruang dan waktu untuk penyimpanan dan pencarian arsip.

Merancang sistem berbasis web untuk mengarsipkan data produksi agar mudah dalam pencarian datanya.

\section{DAFTAR PUSTAKA}

[1]. Abdullah, Dahlan, Cut Yusra Novita dan Cut Ita Erliana,2014, "Perancangan Sistem Informasi Pengarsipan Pada PDAM Tirta Mon Pase Aceh Utara", Jurnal SISFOTENIKA, vol. 4, no. 2.

[2]. Basri dan Joni Devitra, 2017, “Analisis Dan Perancangan Sistem Informasi Pengelolaan Arsip Berbasis Web ( Studi Kasus: Pada Komisi Pemilihan Umum (KPU) Kabupaten Tebo)", Jurnal Manajemen Sistem Informasi, vol. 2, no. 1.

[3]. Kurniawati Yeni dan Ika Ratna Indra Astutik, 2017, "Sistem Informasi Efilling Dokumen Desa Berbasis Web (Studi Kasus : Desa Bangun-Pungging)”, Jurnal Sistem Informasi Teknologi Informatika dan Komputer, vol. 8, no. 1.

[4]. Setyawan, Robi, 2015,"Penerapan Analisis SWOT Sebagai Landasan Merumuskan Strategi Pemasaran Usaha Jasa Sewa Mobil "Aman-Amin" Transport Tour and Travel Ambarketawang Sleman Yogyakarta". Skripsi universitas Negeri Yogyakarta.

[5]. Sidik, Achmad, Sakuroh,Lilis,. dan Diana Pratiwi, 2017, "Perancangan Sistem Informasi Filling di PT BCA Cabang MH Thamrin Tangerang", Jurnal SISFOTEK GLOBAL, vol. 7 , no. 2 .

[6]. Tri Haryono,R., Eka Purnama,B, dan Sukadi., 2013, "Sistem Informasi Pengolahan Data Produksi Dan Penjualan Pada Pabrik Penggergajian Batu CV. Bumi Indah Persada" Scientific Journal Impact Factor. 